\title{
Risk factors associated with anemia among women of reproductive age (15-49) in Albania: A quantile regression analysis
}

\author{
Ashis Talukder ${ }^{\text {a, * }}$, Nupur Paul ${ }^{\mathrm{a}}$, Zahidul Islam Khan ${ }^{\mathrm{a}}$, Benojir Ahammed ${ }^{\mathrm{a}}$, Iqramul Haq ${ }^{\mathrm{b}}$, \\ Mohammad Ali ${ }^{\text {a }}$ \\ ${ }^{a}$ Statistics Discipline, Khulna University, Khulna, 9208, Bangladesh \\ ${ }^{\mathrm{b}}$ Department of Agricultural Statistics, Sher-e-Bangla Agricultural University, Dhaka, 1207, Bangladesh
}

\section{A R T I C L E I N F O}

\section{Keywords:}

Hemoglobin level

Anemia

Risk factors

Quantile regression

Albania

\begin{abstract}
A B S T R A C T
Background: Since anemia is significantly associated with morbidity and mortality among women of reproductive age, identifying the risk factors of anemia remains an important topic of public health. Therefore, this study aims to identify the potential risk factors of anemia among Albanian women of reproductive age.

Methods: For the analysis, the necessary information was collected from a nationally representative secondary dataset, Albania Demographic and Health Survey (ADHS), 2017-18. The anemia status was assessed by the hemoglobin level of the women age 15-49 in Albania. To identify the potential risk factors of anemia, we considered a quantile regression model.

Results: The mean of the respondent's hemoglobin level was 60 with a standard deviation (SD) of 11.73 . The minimum value of the hemoglobin level is 2.00, while the maximum is 99.60. From the estimate of quantile regression, women's education level, wealth index, place of residence, the contraceptive method during pregnancy, body mass index (BMI), and source of drinking water were the significant risk factors for developing anemia among women of reproductive age.

Conclusion: The outcome of this study will help the policymakers design suitable policies and interventions to better address anemia during the childbearing period of women in Albania. Effective strategies to prevent and control anemia should focus on women living in rural areas, not higher educated, not using contraceptive methods during pregnancy, and drinking water is unsafe or underweight.
\end{abstract}

\section{Introduction}

Anemia is a major global public health problems all over the world having significant adverse impact on health, society and economy. ${ }^{1,2}$ Humans can be affected by it at any stage of life. ${ }^{2}$ A systematic review conducted by utilizing both national as well as subnational anemia survey data provide evidence that the estimated worldwide prevalence of anemia is $32.9 \%$ in all ages. ${ }^{3}$ However, the bulk of the anemia burden was reported by women and under-five children.

According to World Health Organization (WHO), anemia is welldefined as a situation in which the hemoglobin concentration within the red blood cells remains lower than average. ${ }^{4}$ The most significant causes for occurring anemia among young adults includes some nutrients deficiencies, particularly iron, vitamin B-12 and A; several infectious diseases including tuberculosis, HIV, malaria, helminthic infection, hookworm and schistosomiasis. ${ }^{5-8}$ However, the actual contributions of these common causes to the global burden of anemia are still not known to us and may be vary by seasonal changes, different dietary practices, genetic and geographical allocation. A study on young Mexican women introduced the 'household food insecurity' as a significant risk factor of anemia. ${ }^{9}$

Since anemia is associated with morbidity and mortality among the women of reproductive age, identification the risk factors of anemia remains an important issue of public health. ${ }^{10}$ In addition, maternal anemia is related to a high risk for low birth weight and inadequate iron store for the newborn. ${ }^{11,12}$ Due to the significant menstrual losses and higher physiologic needs for iron, women of reproductive age suffer from iron deficiency anemia. ${ }^{12}$ At a global level, prevalence and risk factors of anemia remain potential indicators to explore the effective interventions and to assess the progress that was made to reduce the rate

\footnotetext{
* Corresponding author.

E-mail addresses: ashistalukder3168@ku.ac.bd (A. Talukder),nupurst001@gmail.com (N. Paul), zahid.drmc3809@gmail.com (Z.I. Khan), benojirstat@gmail.com (B. Ahammed), iqramul.haq@sau.edu.bd (I. Haq), alirustat@gmail.com (M. Ali).
} 


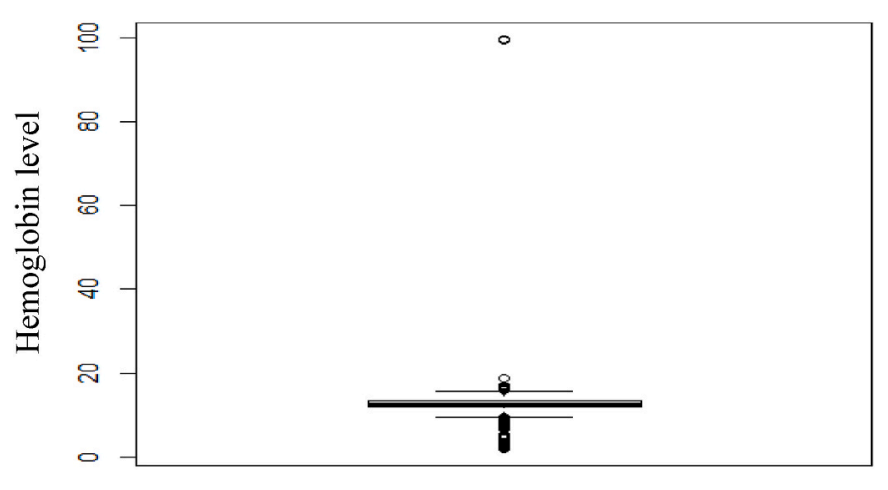

Figure 1: Detecting outliers using box plot

Fig. 1. Detecting outliers using box plot.

of anemia during pregnancy. ${ }^{13}$

Albania is a country in southern Europe, also suffer from anemia. Based on the survey report of 2017-18 ADHS (Albania Demographic and Health Survey), Albanian women age of 15-49 years are anemic approximately $17 \%$, whereas $13 \%$ having minor anemia, $3 \%$ having medium anemia, and the rest of $1 \%$ having acute anemia. ${ }^{14}$ The predominance of anemia among pregnant women in Albania are higher $(22 \%)$ than the women who are neither pregnant nor breastfeeding $(15 \%){ }^{14}$

Anemia among women of reproductive age is a common issue which depends on various factors and obviously vary over time and location, ${ }^{15,16}$ thus needs to be investigated on a regular basis. In the past, most of the examinations have identified the potential risk factors of anemia by utilizing several techniques and various statistical models. ${ }^{17-19}$ A popular logistic regression model was utilized in most of the previous studies. ${ }^{17-21}$ However, anemia is determined by the hemoglobin level which generally measures in a continuous scale. Therefore, multiple linear regression as well as quantile regression can be applied to estimate the effect of several independent variables on hemoglobin level. ${ }^{22}$ However, the quantile regression method has an obvious advantage in a sense that it doesn't characterize only the mean (or median) behavior, which makes quantile regression robust to the presence of outliers and provides a completer and more precise picture of the dataset. ${ }^{23}$ In this study, the hemoglobin status of women is considered the response variable which was found to be skewed and has outliers (see, Box-plot of Fig. 1). Thus, the quantile regression can be used since it should provide more precise result in such scenarios. Therefore, the objective of this research is to identify the risk factors of anemia among women of reproductive age in Albania with the application of quantile regression model.

\section{Methodology}

\subsection{Data source}

The data was obtained from Albania Demographic and Health Survey (ADHS), 2017-18 which is a nationally representative survey. The Institute of Public Health (IPH) and the Institute of Statistics (INSTAT) conducted the survey using the fund from the Swiss Agency for Development and Cooperation (SDC), the United Nations Population Fund (UNFPA), The United Nations Children's Fund (UNICEF) and United Nations Entity for Gender Equality and the Empowerment of Women (UN Women). The online link to download the data is https://dhsprogra m.com/data/available-datasets.cfm. The selection method of the households for the survey was probability proportional to population size and as sample clusters, a total of 715 enumeration areas (EAs) were selected. Then 25 households were randomly selected in every sampling cluster, but all of the households were selected if the selected EA had
Table 1

Description the explanatory variables selected for the study.

\begin{tabular}{ll}
\hline Variables & Description \\
\hline Place of residence & Urban $=1$ \\
& Rural $=2$ \\
Religion & Muslim $=1$ \\
Age & Non-Muslim $=2$ \\
& $15-24=0$ \\
Contraceptive & $25-49=1$ \\
& Not using $=1$ \\
Respondent currently working & Using $=2$ \\
& No $=0$ \\
Highest educational level & Yes $=1$ \\
& No education $=0$ \\
& Primary $=1$ \\
Wealth index & Secondary $=2$ \\
& Higher $=3$ \\
Sources of drinking water & Normal $=0$ \\
Currently Breastfeeding & Middle $=1$ \\
Body mass index & Rich $=2$ \\
& Safe water $=0$ \\
& Unsafe water $=1$ \\
& No =1 \\
& Yes $=2$ \\
& Underweight $=1$ \\
& Normal $=2$ \\
& Overweight $=3$ \\
\hline
\end{tabular}

fewer than 24 households. 10,860 women aged $15-49$ and 4,140 women aged 50-59 were successfully interviewed among the 15,823 households that were selected to conduct the survey. For the analysis of the data, 6.939 and 9,061 women were selected from the urban and rural areas respectively, making a total sample size of 15,000 respondents. The detailed report of the sampling procedure can be obtained from the report of Albania Demographic and Health Survey, 2018. ${ }^{13}$

\subsection{Variables}

The purpose of this study was to find out the risk factor of anemia among women in reproductive age. Thus the main variable of interest of this study was hemoglobin level of the women age 15-49 in Albania.

Along with the main variable, a set of explanatory variables were considered. The detailed description of the selected explanatory variables were shown in Table 1 . Note that, we have considered the following variables that were found to be significant in the previous literature.

\subsection{Statistical analysis}

\subsubsection{Box-plot}

According to Hossain and Majumder, ${ }^{24}$ if the analysis is required to deal with a large number of observations, boxplot is very useful. Moreover, the boxplot uses a five-number summary to present the information about the dataset. The boxplot summarizes the data measured on an interval scale that can be used for identifying if a distribution is skewed and if there are outliers in the dataset, which can be easily visualized by the graphical representation it produces. Thus, it seemed feasible to use in this analysis to detect normality. In this study, based on the findings of the boxplot, we used the quantile regression to analyze the associated factors of low hemoglobin level with anemia. The analysis was conducted using R v4.1.0 and IBM SPSS Statistics Version 20.

\subsubsection{Quantile regression}

Let, $Y$ be any random variable and $F(y)$ be the distribution function can be defined as

$F(y)=\operatorname{Pr}(Y \leq y)$

the $\theta^{\text {th }}$ quantile is defined as 
Table 2

Summary of respondent hemoglobin Status.

\begin{tabular}{|c|c|c|c|c|c|c|}
\hline Mean & Median & Std.deviation & Minimum & Maximum & Skewness & Kurtosis \\
\hline 60 & 14.16 & 11.73 & 2.00 & 99.60 & 7.02 & 48.13 \\
\hline
\end{tabular}

Table 3

Descriptive statistics of selected variable.

\begin{tabular}{|c|c|c|c|}
\hline Variable & Category & Frequency & Percentage $(\%)$ \\
\hline \multirow[t]{2}{*}{ Place of residence } & Urban & 6585 & 41.3 \\
\hline & Rural & 9365 & 58.7 \\
\hline \multirow[t]{2}{*}{ Religion } & Muslim & 13039 & 81.7 \\
\hline & Non-Muslim & 2911 & 18.3 \\
\hline \multirow[t]{2}{*}{ Age } & $15-24$ & 617 & 3.9 \\
\hline & $25-49$ & 15333 & 96.1 \\
\hline \multirow[t]{2}{*}{ Contraceptive } & Not using & 9442 & 59.2 \\
\hline & Using & 6508 & 40.8 \\
\hline \multirow[t]{2}{*}{ Respondent currently working } & No & 10735 & 67.3 \\
\hline & Yes & 5215 & 32.7 \\
\hline \multirow[t]{4}{*}{ Highest educational level } & No education & 144 & 0.9 \\
\hline & Primary & 9533 & 59.8 \\
\hline & Secondary & 4375 & 27.4 \\
\hline & Higher & 1898 & 24.9 \\
\hline \multirow[t]{3}{*}{ Wealth index } & Poor & 9010 & 56.5 \\
\hline & Middle & 2974 & 18.6 \\
\hline & Rich & 3966 & 24.9 \\
\hline \multirow[t]{2}{*}{ Sources of drinking water } & Safe water & 4180 & 26.2 \\
\hline & Unsafe water & 11770 & 73.8 \\
\hline \multirow[t]{2}{*}{ Currently Breastfeeding } & No & 14513 & 91.0 \\
\hline & Yes & 1437 & 9.0 \\
\hline \multirow[t]{3}{*}{ Body mass index } & Under weight & 104 & 0.7 \\
\hline & Normal & 5849 & 36.7 \\
\hline & Over weight & 9997 & 62.7 \\
\hline
\end{tabular}

$Q(\theta)=\inf \{x: F(Y) \geq \theta\}$

for $0<\theta<1, Y$ being a random variable with the distribution function given by equation $(i)$.

Let, $\left(y_{i}, x_{i}\right), i=1,2, \ldots, n$, be a random sample from a population, where $y_{i}$ is a response variable and $x_{i}$ is a set of independent variables. The functional form of the quantile regression model described in Ref. 25 and written as

$y_{i}=x_{i} \beta_{\theta}+\varepsilon_{\theta}$

\section{Results}

The mean of the respondent's hemoglobin level was 60 with a standard deviation (SD) of 11.73. The minimum value of the hemoglobin level is 2.00 , while the maximum is 99.60 . The skewness of the response variables indicates that the distribution of hemoglobin level is positively skewed (Table 2). The outliers were detected using box plot which lets us understand the connection between factors outside of the mean of the data (Fig. 1). That means the data were not normally distributed indicating that the quantile regression analysis would be appropriate for further analysis. Therefore, we performed the quantile regression for different quantiles $(0.1,0.2,0.3,0.4,0.5,0.6,0.7,0.8$, and 0.9 ).

It was observed that among 15,000 respondents, around $41.3 \%$ of respondents are from the urban areas and $59.70 \%$ are from the rural

Table 4

Estimated coefficients of multiple linear regression and quantile regression model for different quantiles with AIC values.

\begin{tabular}{|c|c|c|c|c|c|c|c|c|c|c|c|}
\hline Variable & Category & $\begin{array}{l}\text { OLS p- } \\
\text { value }\end{array}$ & $\begin{array}{l}\mathrm{Q}_{10} \mathrm{P}- \\
\text { value }\end{array}$ & $\begin{array}{l}\mathrm{Q}_{20} \mathrm{P}- \\
\text { value }\end{array}$ & $\begin{array}{l}\mathrm{Q}_{30} \mathrm{p}- \\
\text { value }\end{array}$ & $\begin{array}{l}\mathrm{Q}_{40} \mathrm{p}- \\
\text { value }\end{array}$ & $\begin{array}{l}\mathrm{Q}_{50} \mathrm{P}- \\
\text { value }\end{array}$ & $\begin{array}{l}\mathrm{Q}_{60} \mathrm{p}- \\
\text { value }\end{array}$ & $\begin{array}{l}\mathrm{Q}_{70} \mathrm{p}- \\
\text { value }\end{array}$ & $\begin{array}{l}\mathrm{Q}_{80} \mathrm{p}- \\
\text { value }\end{array}$ & $\begin{array}{l}\mathrm{Q}_{90} \mathrm{P}- \\
\text { value }\end{array}$ \\
\hline Intercept & & $\begin{array}{l}15.77 \\
(0.00)^{*}\end{array}$ & $\begin{array}{l}10.8 \\
(0.00)^{*}\end{array}$ & $\begin{array}{l}10.90 \\
(0.00)^{*}\end{array}$ & $\begin{array}{l}11.36 \\
(0.00)^{*}\end{array}$ & $\begin{array}{l}12.0 \\
(0.00)^{*}\end{array}$ & $\begin{array}{l}12.32 \\
(0.00)^{*}\end{array}$ & $\begin{array}{l}12.67 \\
(0.00)^{*}\end{array}$ & $\begin{array}{l}13.00 \\
(0.00)^{*}\end{array}$ & $\begin{array}{l}13.46 \\
(0.00)^{*}\end{array}$ & $\begin{array}{l}13.92 \\
(0.00)^{*}\end{array}$ \\
\hline ype of place & $\begin{array}{l}\text { Urban(ref) } \\
\text { Rural }\end{array}$ & $\begin{array}{l}-0.90 \\
(0.00)^{*}\end{array}$ & $\begin{array}{l}0.00 \\
(1.00)\end{array}$ & $\begin{array}{l}-0.10 \\
(0.00)^{*}\end{array}$ & $\begin{array}{l}-0.03 \\
(0.27)\end{array}$ & $\begin{array}{l}0.00 \\
(1.00)\end{array}$ & $\begin{array}{l}0.04 \\
(0.09)\end{array}$ & $\begin{array}{l}-0.06 \\
(0.03)^{*}\end{array}$ & $\begin{array}{l}0.00 \\
(1.00)\end{array}$ & $\begin{array}{l}-0.06 \\
(0.02)^{*}\end{array}$ & $\begin{array}{l}-0.14 \\
(0.00)^{*}\end{array}$ \\
\hline Religion & $\begin{array}{l}\text { Muslim(ref) } \\
\text { Non- } \\
\text { Muslim }\end{array}$ & $\begin{array}{l}0.159 \\
(0.51)\end{array}$ & $\begin{array}{l}-0.10 \\
(0.07)\end{array}$ & $\begin{array}{l}0.01 \\
(0.67)\end{array}$ & $\begin{array}{l}0.03 \\
(0.32)\end{array}$ & $\begin{array}{l}0.00 \\
(1.00)\end{array}$ & $\begin{array}{l}0.04 \\
(0.15)\end{array}$ & $\begin{array}{l}0.06 \\
(0.02)^{*}\end{array}$ & $\begin{array}{l}0.00 \\
(1.00)\end{array}$ & $\begin{array}{l}-0.03 \\
(0.17)\end{array}$ & $\begin{array}{c}-0.11 \\
(0.00)^{*}\end{array}$ \\
\hline Respondent Age & $\begin{array}{l}15-24 \text { (ref) } \\
25-49\end{array}$ & $\begin{array}{l}0.49 \\
(0.32)\end{array}$ & $\begin{array}{l}0.00 \\
(1.00)\end{array}$ & $\begin{array}{l}-0.08 \\
(0.28)\end{array}$ & $\begin{array}{l}-0.06 \\
(0.12)\end{array}$ & $\begin{array}{l}-0.10 \\
(0.13)\end{array}$ & $\begin{array}{l}-0.10 \\
(0.01)^{*}\end{array}$ & $\begin{array}{l}-0.05 \\
(0.36)\end{array}$ & $\begin{array}{l}-0.10 \\
(0.00)^{*}\end{array}$ & $\begin{array}{l}-0.06 \\
(0.22)\end{array}$ & $\begin{array}{l}-0.18 \\
(0.00)^{*}\end{array}$ \\
\hline $\begin{array}{l}\text { Current } \\
\text { contraceptive } \\
\text { method }\end{array}$ & $\begin{array}{l}\text { Not using } \\
\text { (ref) } \\
\text { Using }\end{array}$ & $\begin{array}{l}-0.29 \\
(0.12)\end{array}$ & $\begin{array}{l}-0.10 \\
(0.03)\end{array}$ & $\begin{array}{c}-0.13 \\
(0.00)^{*}\end{array}$ & $\begin{array}{l}-0.06 \\
(0.01)^{*}\end{array}$ & $\begin{array}{l}0.00 \\
(1.00)\end{array}$ & $\begin{array}{l}-0.03 \\
(0.10)\end{array}$ & $\begin{array}{l}0.01 \\
(0.81)\end{array}$ & $\begin{array}{l}0.00 \\
(1.00)\end{array}$ & $\begin{array}{l}0.00 \\
(1.00)\end{array}$ & $\begin{array}{l}0.04 \\
(0.00)^{*}\end{array}$ \\
\hline $\begin{array}{l}\text { Highest } \\
\text { educational } \\
\text { level }\end{array}$ & $\begin{array}{l}\text { No } \\
\text { education } \\
\text { (ref) } \\
\text { Primary } \\
\text { Secondary } \\
\text { Higher }\end{array}$ & $\begin{array}{l}-0.68 \\
(0.54) \\
-0.55 \\
(0.57) \\
-0.34 \\
(0.73)\end{array}$ & $\begin{array}{l}-0.20 \\
(0.13) \\
-0.10 \\
(0.42) \\
0.00 \\
(1.00)\end{array}$ & $\begin{array}{l}0.15 \\
(0.00)^{*} \\
0.11 \\
(0.01)^{*} \\
0.25 \\
(0.00)^{*}\end{array}$ & $\begin{array}{l}0.33 \\
(0.00)^{*} \\
0.26 \\
(0.00)^{*} \\
0.36 \\
(0.00)^{*}\end{array}$ & $\begin{array}{l}0.20 \\
(0.19) \\
0.20 \\
(0.20) \\
0.20 \\
(0.20)\end{array}$ & $\begin{array}{l}0.33 \\
(0.00)^{*} \\
0.31 \\
(0.00)^{*} \\
0.28 \\
(0.00)^{*}\end{array}$ & $\begin{array}{l}0.31 \\
(0.00)^{*} \\
0.30 \\
(0.01)^{*} \\
0.34 \\
(0.02)^{*}\end{array}$ & $\begin{array}{l}0.20 \\
(0.15) \\
0.20 \\
(0.16) \\
0.10 \\
(0.48)\end{array}$ & $\begin{array}{l}0.50 \\
(0.00)^{*} \\
0.43 \\
(0.00)^{*} \\
0.43 \\
(0.00)^{*}\end{array}$ & $\begin{array}{l}0.68 \\
(0.00)^{*} \\
0.70 \\
(0.00)^{*} \\
0.72 \\
(0.00)^{*}\end{array}$ \\
\hline Wealth index & $\begin{array}{l}\text { Poor(ref) } \\
\text { Middle } \\
\text { Rich }\end{array}$ & $\begin{array}{l}0.28 \\
(0.00)^{*} \\
0.56 \\
(0.00)^{*}\end{array}$ & $\begin{array}{l}-0.10 \\
(0.10) \\
0.00 \\
(1.00)\end{array}$ & $\begin{array}{l}-0.10 \\
(0.01)^{*} \\
-0.02 \\
(0.60)\end{array}$ & $\begin{array}{l}0.03 \\
(0.39) \\
0.00 \\
(1.00)\end{array}$ & $\begin{array}{l}0.00 \\
(1.00) \\
0.00 \\
(1.00)\end{array}$ & $\begin{array}{l}0.03 \\
(0.32) \\
0.03 \\
(0.35)\end{array}$ & $\begin{array}{l}-0.04 \\
(0.11) \\
-0.05 \\
(0.15)\end{array}$ & $\begin{array}{l}0.00 \\
(1.00) \\
0.00 \\
(1.00)\end{array}$ & $\begin{array}{l}0.00 \\
(1.00) \\
0.03 \\
(0.34)\end{array}$ & $\begin{array}{l}0.08 \\
(0.00)^{*} \\
-0.04 \\
(0.00)^{*}\end{array}$ \\
\hline $\begin{array}{l}\text { Source of } \\
\text { drinking water }\end{array}$ & $\begin{array}{l}\text { Safe(ref) } \\
\text { Not safe }\end{array}$ & $\begin{array}{l}-066 \\
(0.00)^{*}\end{array}$ & $\begin{array}{l}0.00 \\
(1.00)\end{array}$ & $\begin{array}{l}-0.05 \\
(0.03)^{*}\end{array}$ & $\begin{array}{l}-0.13 \\
(0.00)^{*}\end{array}$ & $\begin{array}{l}-0.10 \\
(0.00)^{*}\end{array}$ & $\begin{array}{l}-0.13 \\
(0.00)^{*}\end{array}$ & $\begin{array}{l}-0.12 \\
(0.00)^{*}\end{array}$ & $\begin{array}{l}-0.10 \\
(0.00)^{*}\end{array}$ & $\begin{array}{l}-0.13 \\
(0.00)^{*}\end{array}$ & $\begin{array}{l}-0.17 \\
(0.00)^{*}\end{array}$ \\
\hline $\begin{array}{l}\text { Respondent } \\
\text { currently } \\
\text { working }\end{array}$ & $\begin{array}{l}\text { No(ref) } \\
\text { Yes }\end{array}$ & $\begin{array}{l}0.47 \\
(0.02)^{*}\end{array}$ & $\begin{array}{l}0.10 \\
(0.06)\end{array}$ & $\begin{array}{l}0.05 \\
(0.11)\end{array}$ & $\begin{array}{l}0.10 \\
(0.00)^{*}\end{array}$ & $\begin{array}{l}0.10 \\
(0.01)^{*}\end{array}$ & $\begin{array}{l}0.12 \\
(0.00)^{*}\end{array}$ & $\begin{array}{l}0.12 \\
(0.00)^{*}\end{array}$ & $\begin{array}{l}0.10 \\
(0.00)^{*}\end{array}$ & $\begin{array}{l}0.06 \\
(0.01)^{*}\end{array}$ & $\begin{array}{l}0.01 \\
(0.00) *\end{array}$ \\
\hline Body Mass Index & $\begin{array}{l}\text { Under } \\
\text { weight(ref) } \\
\text { Normal } \\
\text { Over } \\
\text { weight }\end{array}$ & $\begin{array}{l}-0.35 \\
(0.76) \\
-1.03 \\
(0.31)\end{array}$ & $\begin{array}{l}0.40 \\
(0.43) \\
0.30 \\
(0.56)\end{array}$ & $\begin{array}{l}0.89 \\
(0.00)^{*} \\
0.83 \\
(0.00) *\end{array}$ & $\begin{array}{l}0.53 \\
(0.21) \\
0.60 \\
(0.16)\end{array}$ & $\begin{array}{l}0.30 \\
(0.00)^{*} \\
0.40 \\
(0.00)^{*}\end{array}$ & $\begin{array}{l}0.11 \\
(0.20) \\
0.27 \\
(0.00)^{*}\end{array}$ & $\begin{array}{l}0.15 \\
(0.22) \\
0.26 \\
(0.36)\end{array}$ & $\begin{array}{l}0.20 \\
(0.38) \\
0.30 \\
(0.19)\end{array}$ & $\begin{array}{l}-0.16 \\
(0.55) \\
0.00 \\
(1.00)\end{array}$ & $\begin{array}{l}-0.05 \\
(0.00)^{*} \\
0.05 \\
(0.00)^{*}\end{array}$ \\
\hline AIC & & 123760.1 & 82604.19 & 80066.91 & 80087.44 & 81628.95 & 84471.17 & 88756.07 & 95118.03 & 105139.6 & 123928.4 \\
\hline
\end{tabular}

N.B. “*” indicate for $95 \%$ confidence level. 
areas of Albania. It was found $0.9 \%$ of the respondents had no education, $59.8 \%$ had primary education, $27.4 \%$ had secondary education and $24.9 \%$ had higher educational level. It was observed that about only $26 \%$ of individuals had access to safe drinking water while $74 \%$ did not. We also see that about $56 \%$ of women come from a poor family, on the other hand about $18 \%$ and $24 \%$ of women are from middle and rich family respectively (see, Table 3 ).

Taking the value of AIC for different quantiles and the OLS model into consideration, we select the 20th quantile regression because it provides the lowest AIC value (see, Table 4). Therefore, we will focus on the estimates of the 20th quantile regression model, which shows that eight variables out of the eleven independent variables have showed significant results, considering the level of significance at $\alpha=0.05$.

From the estmate of quantile regression $\left(Q_{20}\right)$, we found that place of residence (Estimate $=-0.102$ ) has a negative impact on the hemoglobin status of the respondent, which means that the respondents living in the rural areas have significantly $(\mathrm{p}<0.001)$ lower hemoglobin level than the respondents who live in the urban areas. In terms of contraceptives, it has a negative (Estimate $=-0.132$ ) impact on the hemoglobin status of the respondent, meaning that the respondents who use contraceptives have significantly $(\mathrm{p}<0.03)$ lower level of hemoglobin status than the respondent who do not use them. All three categories of the respondent's education such as primary (Estimate $=0.152$ ), secondary (Estimate $=$ 0.114 ), and higher (Estimate $=0.251$ ) have positive impact on the hemoglobin status of the respondent. That means the respondents who are educated have significantly $(\mathrm{p}<0.001$ ) higher hemoglobin status than the respondent who are not educated. It is observed that belonging to middle class (Estimate $=-0.130$ ) or rich (Estimate $=-0.012$ ) families has negative impact on the hemoglobin status. Additionally, the source of drinking water also has a negative (Estimate $=-0.05$ ) impact on the hemoglobin status of the respondent. The two categories of body mass index (BMI), normal (Estimate $=0.891$ ) and overweight (Estimate $=$ 0.832 ) have positive impact on the hemoglobin status of the respondent, which means that the hemoglobin level is significantly $(p<0.001)$ higher among normal and overweight respondents than the respondents who are underweight.

\section{Discussion}

In our analysis, we observe that the women who lived in rural region were more likely to be anemic than the women lived in urban areas of Albania. The limited availability of nutritious foods, lower socioeconomic status, and lack of access to hygienic sanitation facilities associated with elevated rates of disease which in turn may associated with increased risk of anemia in rural areas. ${ }^{3}$

Using of contraception method also found to be a significant risk factors for reducing the rate of anemia. Based on our analysis, the respondents who use contraceptive methods were less likely to affect by anemia than the respondent who does not use the contraceptive method. In the literature, we found that among women currently using contraceptive methods, the risk of anemia was lower than the women who did not use contraception methods. ${ }^{26}$

Education was found to be a significant factor in anemia status. We observed that the respondents who are educated were less likely to be anemic than the respondent who is not educated. The respondents who lack proper education do not know the consequence of a low hemoglobin level. ${ }^{27}$ They have also lacked the knowledge of family planning and the risk of any disease. Moreover, the level of education is confounding with socioeconomic status in general, but may also be reflected in the relatively poorer understanding of the optimum child care and nutritional practices. ${ }^{28}$ The study results in this regard are consistent with the literature. ${ }^{28}$ The respondents of the middle and rich-income households had a lower prevalence of anemia compared to the poor class household. This finding is also consistent with previous studies. $^{29-31}$

The variable source of drinking water has a significant impact on the hemoglobin status of the respondent. Based on quantile regression model the respondent who drinking safe water is less affected by anemia than drinking the unsafe water. Our findings coincide with previous studies. $^{32}$

The Body Mass Index (BMI) has a positive impact on the hemoglobin status of the respondent. The overweight women were less likely to be anemic than underweight women. This findings contradicts with several previous studies. ${ }^{33,34}$ This may be due to the geographical location, different dataset as well as statistical models we have utilized in this study.

\section{Conclusion}

We used quantile regression model to identify the potential risk factors of anemia in Albania. This study demonstrated that women's education level, wealth index, place of residence, using contraceptive method during pregnancy, body mass index (BMI), and source of drinking water were the significant risk factors for developing anemia among women of reproductive age. These factors will help the policymakers to design policies and interventions to better address of anemia during the childbearing period of women in Albania. Effective strategies to prevent and control of anemia should be focus on women who are living in rural area, not higher educated, not using contraceptive method during pregnancy, source of drinking water is safe or underweight.

\section{Ethical approval}

This study was conducted analyzing publicly available ADHS data from demographic health surveys. The ADHS was approved by the Institute of Public Health (IPH) and the Institute of Statistics (INSTAT). ICF Macro Institutional Review Board in Calverton, Maryland, USA also provided partial technical assistance to approve the project. The writ-ten consent form was taken from all survey participants. Hence, additional ethical approval was not necessary in this study, as the analysis was based on secondary data.

\section{Declaration of competing interest}

The authors declare that they have no competing interests.

\section{References}

1 McLean E, Cogswell M, Egli I, Wojdyla D, De Benoist B. Worldwide prevalence of anaemia, WHO vitamin and mineral nutrition information system, 1993-2005. Publ Health Nutr. 2009;12(4):444-454. Apr.

2 Stevens GA, Finucane MM, De-Regil LM, et al. Nutrition Impact Model Study Group. Global, regional, and national trends in haemoglobin concentration and prevalence of total and severe anaemia in children and pregnant and non-pregnant women for 1995-2011: a systematic analysis of population-representative data. Lancet Global Health. 2013;1(1):e16-25. Jul.

3 Kassebaum NJ, Jasrasaria R, Naghavi M, et al. A systematic analysis of global anemia burden from 1990 to 2010. Blood. 2014;123(5):615-624. Jan.

4 WHO https://www, who.int/health-topics/anaemia\#tab=tab 1.

5 Conway G, Sechler S. Helping Africa feed itself. Sep Science. 2000;289(5485), 16851685.

6 Guyatt HL, Snow RW. The epidemiology and burden of Plasmodium falciparumrelated anemia among pregnant women in sub-Saharan Africa. Am J Trop Med Hyg. 2001;64(1_suppl):36-44. Jan.

7 Asobayire FS, Adou P, Davidsson L, Cook JD, Hurrell RF. Prevalence of iron deficiency with and without concurrent anemia in population groups with high prevalences of malaria and other infections: a study in Cote d'Ivoire. Am J Clin Nutr. 2001;74(6):776-782. Dec.

8 Ter Kuile FO, Parise ME, Verhoeff FH, et al. The burden of co-infection with human immunodeficiency virus type 1 and malaria in pregnant women in sub-saharan Africa. Am J Trop Med Hyg. 2004;71(2_suppl):41-54. Aug.

9 Fischer NC, Shamah-Levy T, Mundo-Rosas V, Méndez-Gómez-Humarán I, PérezEscamilla R. Household food insecurity is associated with anemia in adult Mexican women of reproductive age. J Nutr. 2014;144(12):2066-2072. Dec.

10 Aziz Ali S, Abbasi Z, Feroz A, et al. Factors associated with anemia among women of the reproductive age group in Thatta district: study protocol. Reprod Health. 2019;16: 34. https://doi.org/10.1186/s12978-019-0688-7.

11 Brabin BJ, Premji Z, Verhoeff F. An analysis of anemia and child mortality. J Nutr. 2001;131(2):636S-648S. Feb. 
12 Scholl TO, Hediger ML, Fischer RL, Shearer JW. Anemia vs iron deficiency: increased risk of preterm delivery in a prospective study. Am J Clin Nutr. 1992;55(5):985-988. May.

13 World Health Organization. The World Health Report 2002: Reducing Risks, Promoting Healthy Life. World Health Organization; 2002. Available from: http://www.who. int/whr/2002/en/whr02_en.pdf.

14 Institute of Statistics. Institute of Public Health, and ICF Albania Demographic and Health Survey 2017-18. Tirana, Albania: Institute of Statistics, Institute of Public Health, and ICF; 2018.

15 Chowdhury HA, Ahmed KR, Jebunessa F, Akter J, Hossain S, Shahjahan M. Factors associated with maternal anaemia among pregnant women in Dhaka city. BMC Wom Health. 2015;15(1):1-6. Dec.

16 Kofie P, Tarkang EE, Manu E, et al. Prevalence and associated risk factors of anaemia among women attending antenatal and post-natal clinics at a public health facility in Ghana. BMC Nutr. 2019;5(1):1-9. Dec.

17 Mockenhaupt FP, Rong B, Günther M, et al. Anaemia in pregnant Ghanaian women: importance of malaria, iron deficiency, and haemoglobinopathies. Trans $R$ Soc Trop Med Hyg. 2000;94(5):477-483. Sep.

18 Gaillard R, Eilers PH, Yassine S, Hofman A, Steegers EA, Jaddoe VW. Risk factors and consequences of maternal anaemia and elevated haemoglobin levels during pregnancy: a population-based prospective cohort study. Paediatr Perinat Epidemiol. 2014;28(3):213-226. May.

19 Hakizimana D, Nisingizwe MP, Logan J, Wong R. Identifying risk factors of anemia among women of reproductive age in Rwanda-a cross-sectional study using secondary data from the Rwanda demographic and health survey 2014/2015. BMC Publ Health. 2019;19(1):1-11. Dec.

20 Bentley ME, Griffiths PL. The burden of anemia among women in India. Eur J Clin Nutr. 2003;57(1):52-60. Jan.

21 Harding KL, Aguayo VM, Namirembe G, Webb P. Determinants of anemia among women and children in Nepal and Pakistan: an analysis of recent national survey data. Matern Child Nutr. 2018;14, e12478. Nov.

22 Schneider JM, Fujii ML, Lamp CL, Lönnerdal B, Dewey KG, Zidenberg-Cherr S. The use of multiple logistic regression to identify risk factors associated with anemia and iron deficiency in a convenience sample of 12-36-mo-old children from low-income families. Am J Clin Nutr. 2008;87(3):614-620. https://doi.org/10.1093/ajcn/ 87.3.614. Mar, PMID: 18326599.

23 Yeh CC, Wang KM, Suen YB. Quantile analyzing the dynamic linkage between inflation uncertainty and inflation. Probl Perspect Manag. 2009;7(1):21-28.

24 Hossain MM, Majumder AK. Determinants of the age of mother at first birth in Bangladesh: quantile regression approach. J Publ Health. 2019;27(4):419-424. Aug.

25 Buchinsky M. The dynamics of changes in the female wage distribution in the USA: a quantile regression approach. $J$ Appl Econom. 1998;13(1):1-30. Jan.

26 Heck JE, Chen Y, Grann VR, Slavkovich V, Parvez F, Ahsan H. Arsenic exposure and anemia in Bangladesh: a population-based study. J Occup Environ Med. 2008;50(1): 80-87. Jan.

27 GG Kingdon and J Knight. Poverty and Income. Retrieved November 22, 2020,from The Poverty Group: http://devdata.worldbank.org/hnpstats/pvd.asp.

28 Ahmed S, Hasan MM, Ahmed W, Chowdhury MA. Socio-economic inequity of malnutrition among under-five children and women at reproductive age in Bangladesh. J Nutr Health. 2013;1:13-17.

29 Hyder SZ, Persson LÅ, Chowdhury M, Lönnerdal BO, Ekström EC. Anaemia and iron deficiency during pregnancy in rural Bangladesh. Publ Health Nutr. 2004;7(8): 1065-1070. Dec.

30 Kamruzzaman M, Rabbani MG, Saw A, Sayem MA, Hossain MG. Differentials in the prevalence of anemia among non-pregnant, ever-married women in Bangladesh: multilevel logistic regression analysis of data from the 2011 Bangladesh Demographic and Health Survey. BMC Wom Health. 2015;15(1):1-8. Dec.

31 Zahangir MS, Hasan MM, Richardson A, Tabassum S. Malnutrition and noncommunicable diseases among Bangladeshi women: an urban-rural comparison. Mar Nutr Diabetes. 2017;7(3). e250- e250.

32 Habyarimana F, Zewotir T, Ramroop S. Prevalence and risk factors associated with anemia among women of childbearing age in Rwanda. Afr J Reprod Health. 2020;24 (2):141-151. Jul.

33 Ghose B, Yaya S, Tang S. Anemia status in relation to body mass index among women of childbearing age in Bangladesh. Asia Pac J Publ Health. 2016;28(7):611-619. Oct.

34 Adamu AL, Crampin A, Kayuni N, et al. Prevalence and risk factors for anemia severity and type in Malawian men and women: urban and rural differences. Popul Health Metrics. 2017;15(1):1-15. Dec. 